\title{
Risk factors for severe PCR-positive SARS-CoV-2 infection in hospitalized children: a multicenter cohort study
}

Tilmann Schober $\mathrm{MD}^{1}$, Chelsea Caya $\mathrm{MscPH}^{2}$, Michelle Barton $\mathrm{MD}^{3}$, Ann Bayliss $\mathrm{MD}^{4}$, Ari Bitnun $\mathrm{MD}^{5}$, Jennifer Bowes MSc${ }^{6}$, Helena Brenes-Chacon MD ${ }^{7}$, Jared Bullard MD ${ }^{8}$, Suzette Cooke MD ${ }^{9}$, Tammie Dewan $\mathrm{MD}^{9}$, Rachel Dwilow MD ${ }^{8}$, Tala El Tal MD ${ }^{5}$, Cheryl Foo MD ${ }^{10}$, Peter Gill MD ${ }^{5}$, Behzad Haghighi Aski MD ${ }^{11}$, Fatima Kakkar MD ${ }^{12}$, Janell Lautermilch MD ${ }^{14}$, Ronald M. Laxer MD Marie-Astrid Lefebvre MD ${ }^{1}$, Kirk Leifso $\mathrm{MD}^{15}$, Nicole Le Saux $\mathrm{MD}^{6}$, Alison Lopez MD ${ }^{13}$, Ali Manafi $\mathrm{MD}^{11}$, Shaun K. Morris MD ${ }^{5}$, Alireza Nateghian MD ${ }^{11}$, Luc Panetta MD ${ }^{12}$, Dara Petel MD ${ }^{5}$, Dominique Piché $\mathrm{MD}^{18}$, Rupeena Purewal MD ${ }^{14}$, Lea Restivo MD ${ }^{9}$, Ashley Roberts $\mathrm{MD}^{13,16}$, Manish Sadarangani MD ${ }^{13,16,17}$, Rosie Scuccimarri MD ${ }^{1}$, Alejandra Soriano-Fallas MD ${ }^{7}$, Sarah Tehseen MD, ${ }^{14}$ Karina A. Top $\mathrm{MD}^{18}$, Rolando Ulloa-Gutierrez $\mathrm{MD}^{7}$, Isabelle Viel-Thériault $\mathrm{MD}^{19}$, Jacqueline K. Wong $\mathrm{MD}^{20}$, Carmen $\mathrm{Yea}^{5}$, Ann Yeh MD ${ }^{5}$, Adriana Yock-Corrales MD ${ }^{7}$, Joan Robinson MD ${ }^{21}$, Jesse Papenburg $\mathrm{MD}^{1,2}$

\footnotetext{
Affiliations:

${ }^{1}$ Department of Pediatrics, McGill University, Montreal, Quebec, Canada

${ }^{2}$ Research Institute of the McGill University Health Centre, Montreal, Quebec, Canada

${ }^{3}$ Department of Pediatrics, Western University, London, Ontario, Canada

${ }^{4}$ Department of Pediatrics, Trillium Health Partners, Mississauga, Ontario, Canada

${ }^{5}$ Department of Pediatrics, University of Toronto, Toronto, Ontario, Canada

${ }^{6}$ Department of Pediatrics, University of Ottawa, Ottawa, Ontario, Canada

${ }^{7}$ Department of Pediatrics, Hospital Nacional de Niños "Dr. Carlos Sáenz Herrera", Caja Costarricense de

Seguro Social (CCSS); San José, Costa Rica

${ }^{8}$ Department of Pediatrics, University of Manitoba, Winnipeg, Manitoba, Canada

${ }^{9}$ Department of Pediatrics, University of Calgary, Calgary, Alberta, Canada

${ }^{10}$ Department of Pediatrics, Memorial University, St John's, Newfoundland and Labrador, Canada

${ }^{11}$ Department of Pediatrics, Iran University of Medical Sciences, Tehran, Iran

${ }^{12}$ Department of Pediatrics, Université de Montréal, Montreal, Quebec, Canada

${ }^{13}$ British Columbia Children's Hospital, Vancouver, British Columbia, Canada

${ }^{14}$ Department of Pediatrics, University of Saskatchewan, Saskatoon, Saskatchewan, Canada

${ }^{15}$ Department of Pediatrics, Queen's University, Kingston, Ontario, Canada

${ }^{16}$ Department of Pediatrics, University of British Columbia, Vancouver, British Columbia, Canada

${ }^{17}$ Vaccine Evaluation Center, BC Children's Hospital Research Institute, Vancouver, British Columbia, Canada

${ }^{18}$ Department of Pediatrics, Dalhousie University, Halifax, Nova Scotia, Canada

${ }^{19}$ Department of Pediatrics, CHU de Québec-Université Laval, Quebec, Quebec, Canada

${ }^{20}$ Department of Pediatrics, McMaster University, Hamilton, Ontario, Canada

${ }^{21}$ Department of Pediatrics, University of Alberta, Edmonton, Alberta, Canada
} 
medRxiv preprint doi: https://doi.org/10.1101/2021.10.28.21265616; this version posted November 8, 2021. The copyright holder for this preprint

(which was not certified by peer review) is the author/funder, who has granted medRxiv a license to display the preprint in perpetuity.

It is made available under a CC-BY-NC-ND 4.0 International license.

\section{Address correspondence to:}

Dr. Jesse Papenburg

Montreal Children's Hospital, McGill University Health Centre

E05.1905 - 1001 Décarie Blvd, Montréal, QC, H4A 3J1

Canada

Phone: (514) 412-4485

jesse.papenburg@mcgill.ca

Dr. Joan L Robinson

Stollery Children's Hospital

4-590 ECHA, 11405-87 Ave, Edmonton, AB, T6G 1C9

Canada

Phone: (780) 248-5528

jr3@ualberta.ca

Manuscript word count: 2999 
medRxiv preprint doi: https://doi.org/10.1101/2021.10.28.21265616; this version posted November 8, 2021. The copyright holder for this preprint

(which was not certified by peer review) is the author/funder, who has granted medRxiv a license to display the preprint in perpetuity.

It is made available under a CC-BY-NC-ND 4.0 International license.

\section{Key points}

Question: What are the risk factors for severe disease in children hospitalized for PCR-positive SARSCoV-2 infection?

Findings: In this multinational cohort study of 403 children, multiple comorbidities, obesity, neurological disorder, anemia, and/or hemoglobinopathy, shortness of breath, bacterial and/or viral coinfections, chest imaging compatible with COVID-19, neutrophilia, and MIS-C diagnosis were independent risk factors for severity. The risk profile and presence of comorbidities differed between pediatric age groups, but age itself was not associated with severe outcomes.

Meaning: These results can inform targeted treatment approaches and vaccine programs that focus on patient groups with the highest risk of severe outcomes. 
medRxiv preprint doi: https://doi.org/10.1101/2021.10.28.21265616; this version posted November 8, 2021. The copyright holder for this preprint (which was not certified by peer review) is the author/funder, who has granted medRxiv a license to display the preprint in perpetuity.

It is made available under a CC-BY-NC-ND 4.0 International license .

\section{Abstract}

Importance: Children are less likely than adults to have severe outcomes from SARS-CoV-2 infection and the corresponding risk factors are not well established.

Objective: To identify risk factors for severe disease in symptomatic children hospitalized for PCRpositive SARS-CoV-2 infection.

Design: Cohort study, enrollment from February 1, 2020 until May 31, 2021

Setting 15 children's hospitals in Canada, Iran, and Costa Rica

Participants: Patients <18 years of age hospitalized with symptomatic SARS-CoV-2 infection, including PCR-positive multisystem inflammatory syndrome in children (MIS-C)

Exposures: Variables assessed for their association with disease severity included patient demographics, presence of comorbidities, clinical manifestations, laboratory parameters and chest imaging findings.

Main Outcomes and Measures: The primary outcome was severe disease defined as a WHO COVID19 clinical progression scale of $\geq 6$, i.e., requirement of non-invasive ventilation, high flow nasal cannula, mechanical ventilation, vasopressors, or death. Multivariable logistic regression was used to evaluate factors associated with severe disease.

Results: We identified 403 hospitalizations. Median age was 3.78 years (IQR 0.53-10.77). At least one comorbidity was present in $46.4 \%$ (187/403) and multiple comorbidities in $18.6 \%(75 / 403)$. Severe disease occurred in $33.8 \%$ (102/403). In multivariable analyses, presence of multiple comorbidities (adjusted odds ratio 2.24, 95\% confidence interval 1.04-4.81), obesity (2.87, 1.19-6.93), neurological disorder (3.22, 1.37-7.56), anemia, and/or hemoglobinopathy (5.88, 1.30-26.46), shortness of breath (4.37, 2.08-9.16), bacterial and/or viral coinfections $(2.26,1.08-4.73)$, chest imaging compatible with COVID-19 (2.99, 1.51-5.92), neutrophilia (2.60, 1.35-5.02), and MIS-C diagnosis (3.86, 1.56-9.51) were independent risk factors for severity. Comorbidities, especially obesity $(40.9 \%$ vs $3.9 \%, \mathrm{p}<0.001)$, were more frequently present in adolescents $\geq 12$ years of age. Neurological disorder $(3.16,1.19-8.43)$ in 
medRxiv preprint doi: https://doi.org/10.1101/2021.10.28.21265616; this version posted November 8, 2021. The copyright holder for this preprint (which was not certified by peer review) is the author/funder, who has granted medRxiv a license to display the preprint in perpetuity. It is made available under a CC-BY-NC-ND 4.0 International license.

children $<12$ years of age and obesity $(3.21,1.15-8.93)$ in adolescents were the specific comorbidities associated with disease severity in age-stratified adjusted analyses. Sensitivity analyses excluding the 81 cases with MIS-C did not substantially change the identified risk factors.

Conclusions and Relevance: Pediatric risk factors for severe SARS-CoV-2 infection vary according to age and can potentially guide vaccination programs and treatment approaches in children. 
medRxiv preprint doi: https://doi.org/10.1101/2021.10.28.21265616; this version posted November 8, 2021. The copyright holder for this preprint (which was not certified by peer review) is the author/funder, who has granted medRxiv a license to display the preprint in perpetuity. It is made available under a CC-BY-NC-ND 4.0 International license .

\section{Introduction}

The clinical presentation of severe acute respiratory syndrome coronavirus-2 (SARS-CoV-2) infection is generally milder in children than in adults. However, children can also experience morbidity and mortality due to coronavirus disease 2019 (COVID-19). ${ }^{1}$ It is important to identify risk factors for severe disease. This would allow for identification of patient groups that require closer monitoring or early treatment, and could also help guide targeted vaccination campaigns.

While many countries started a vaccination program against SARS-CoV-2 for all adolescents older than 11 years of age in June/July 2021, others had limited access to vaccines or decided to focus on high-risk groups following WHO recommendations. ${ }^{2,3}$ Considering the usually benign clinical course of SARSCoV-2 infection in children, the potential direct and societal benefits of universal versus targeted vaccination in the pediatric population need to be considered carefully. It is therefore of great practical value to know which children are at high risk of severe disease.

Previous studies have attempted to identify risk factors for severe disease in pediatric patients for severe SARS-CoV-2 infection. ${ }^{4-14}$ Some risk factors such as presence of comorbidities, obesity, and increased inflammatory markers have been implicated, ${ }^{5,8,10-13,15}$ but many studies were small and there is substantial heterogeneity. ${ }^{16}$ Importantly, most major studies were from high-income countries and data from low and middle-income countries are scarce.

Multisystem inflammatory syndrome in children (MIS-C) is a serious post-infectious complication of SARS-CoV-2 infection in children. Despite differences in the pathophysiology and clinical presentation, ${ }^{17,18}$ there is significant overlap between acute SARS-CoV-2 infection and PCR-positive MIS-C; it is frequently impossible to distinguish them and both contribute to the potentially preventable burden of SARS-CoV-2 in children. 
medRxiv preprint doi: https://doi.org/10.1101/2021.10.28.21265616; this version posted November 8, 2021. The copyright holder for this preprint (which was not certified by peer review) is the author/funder, who has granted medRxiv a license to display the preprint in perpetuity.

It is made available under a CC-BY-NC-ND 4.0 International license .

The aim of this study was the identification of risk factors for severe disease in children hospitalized for symptomatic PCR-confirmed SARS-CoV-2 infection including PCR-positive MIS-C in a multicenter cohort study from Canada, Costa Rica, and Iran.

\section{Methods}

\section{Study Design and Population}

Thirteen pediatric hospitals from the Canadian Pediatric Investigators Collaborative Network on Infections in Canada (PICNIC) group and two international collaborators (one each in Tehran, Iran, and San José, Costa Rica) entered all consecutive children <18 years of age admitted from February 1, 2020 through May 31, 2021 with PCR confirmed SARS-CoV-2 infection or MIS-C. Cases were identified through the microbiology laboratory, infection prevention and control and/or COVID-19 unit databases. The present study was restricted to symptomatic cases with detection of SARS-CoV-2 by molecular testing from a respiratory specimen during the current admission. Patients who were admitted for reasons other than their SARS-CoV-2 infection (i.e. incidental infections), as per each local investigator's adjudication, were excluded.

Ethics approval was obtained from each participating institution's ethics research board, with waiver for informed consent for health records research (Supplementary methods). The STrengthening the Reporting of OBservational studies in Epidemiology (STROBE) guidelines were followed. ${ }^{19}$ 
medRxiv preprint doi: https://doi.org/10.1101/2021.10.28.21265616; this version posted November 8, 2021. The copyright holder for this preprint (which was not certified by peer review) is the author/funder, who has granted medRxiv a license to display the preprint in perpetuity.

It is made available under a CC-BY-NC-ND 4.0 International license .

\section{Data Collection}

Data on primary indication for admission, demographics, comorbidities, clinical presentation and course, coinfections, treatments, and complications were abstracted by the investigators from the patient's medical charts and managed using REDCap electronic data capture tools.

\section{Variables of Interest and Study Definitions}

The primary outcome, severe PCR-positive SARS-CoV-2 infection, was defined as a WHO clinical progression scale ${ }^{20}$ of $\geq 6$, i.e. oxygen by non-invasive ventilation or high flow or mechanical ventilation or vasopressors or death. For a secondary analysis, severe SARS-CoV-2 infection was defined as a WHO clinical progression scale $^{20}$ of $\geq 6$ and/or admission to an intensive care unit (ICU). Baseline exposure variables included age, sex country of admission, admission period (arbitrarily divided into prior to July 1, 2020; July 1 until Dec 31 2020; Jan 1 until May 31, 2021), and comorbidities. These chronic health conditions were classified using the Canadian National Advisory Committee on Immunization risk group classification for influenza ${ }^{21}$ and adapted according to putative risk factors for severe COVID-19 in children (Supplementary methods). Other potential predictor variables (measured at any point during the hospitalization) were: clinical manifestations, viral co-infection (defined as laboratory detection of any other virus; testing at the discretion of the clinical team), bacterial co-infection (defined as laboratory detection of $\geq 1$ bacteria treated with antibiotics; testing and treatment at the discretion of the clinical team), chest imaging abnormalities (chest x-ray or CT compatibility with COVID-19 based on the reporting physician's assessment), laboratory parameters (age-defined leukocytosis, leukopenia, neutrophilia, neutropenia, thrombocytosis or thrombocytopenia ${ }^{22}$; C-reactive Protein [CRP] >50mg/L; Ferritin >5000 mcg/L; albumin <29g/L), diagnosis of MIS-C (as defined by WHO criteria ${ }^{23}$ ). 
medRxiv preprint doi: https://doi.org/10.1101/2021.10.28.21265616; this version posted November 8, 2021. The copyright holder for this preprint (which was not certified by peer review) is the author/funder, who has granted medRxiv a license to display the preprint in perpetuity.

It is made available under a CC-BY-NC-ND 4.0 International license .

\section{Data Analysis}

Data were analyzed using R version 3.5.2 (R Core Team, Vienna, Austria). Statistical significance was assessed by using 2-tailed tests, with an $\alpha$ of 0.05 . Baseline and demographic characteristics were summarized using descriptive statistics. Categorical data were compared using chi-square or Fisher's exact test as appropriate and continuous data compared using Wilcoxon rank sum test. Statistical testing was limited to hypothesis-driven and biologically plausible comparisons; accordingly, correction for multiple hypothesis testing was not done. Logistic regression analyses were performed to determine crude and adjusted odds ratios (aORs) and corresponding 95\% confidence intervals (CIs) for factors associated with se1vere disease. For the multivariable models, we considered variables with p-value $\leq 0.2$ on univariable analyses and, a priori, variables which were potential confounders based on literature or clinical experience. Model selection was guided by Akaike Information Criteria, using backward and forward selection. Pre-specified sensitivity (excluding MIS-C cases) and age-stratified analyses (children under 12 years old and adolescents $\geq 12$ years old) were also performed. 
medRxiv preprint doi: https://doi.org/10.1101/2021.10.28.21265616; this version posted November 8, 2021. The copyright holder for this preprint (which was not certified by peer review) is the author/funder, who has granted medRxiv a license to display the preprint in perpetuity.

It is made available under a CC-BY-NC-ND 4.0 International license .

\section{Results}

From February 1, 2020 through May 31, 2021, 982 children younger than 18 years of age hospitalized for SARS-CoV-2-related illness and/or PCR-positive MIS-C were reported from the 15 study hospitals. We excluded 579 cases in whom SARS-CoV-2 was not confirmed by molecular testing from respiratory specimens or because the patient was admitted for non-SARS-CoV-2-related reasons. We included the remaining 403 hospitalizations (Figure 1).

\section{Demographics and Clinical Characteristics}

Hospitalizations occurred from March 19 2020 through May 31 ${ }^{\text {st }} 2021 ; 266$ cases $(66 \%)$ were from Canada, 107 (27\%) from Costa Rica, and 30 (7\%) from Iran (Tables 1 and 2). Overall median age was 3.78 years (interquartile range [IQR]: 0.53-10.77). At least 1 comorbidity was present in $46.4 \%$ and multiple comorbidities in $18.6 \%$ of children. Fever (82.1\%), cough (51.6\%), shortness of breath (46.7\%), vomiting (31.5\%), rhinitis (31\%), diarrhea (28.5\%), and abdominal pain (26.8\%) were the most common presenting symptoms. Intensive care unit (ICU) admission was required in 115 patients (28.5\%). Six patients died, all with comorbidities, including 2 patients with malignancies receiving palliative care.

Compared to the two middle-income countries, cases from Canada were older (median 5.82 [IQR 0.8414.27] vs 2.15 [IQR: 0.48-6.01] years) with a higher proportion of adolescents $(32.8 \%$ vs $5.6 \%$, p<0.001) and occurred later during the study period (66.5\% vs $40.8 \%$ admitted in $2021, \mathrm{p}<0.001)$. Other key demographic, clinical and outcome parameters were similar between countries, including length of hospitalization, proportion requiring ICU admissions, severity according to WHO definition and percentage of cases with MIS-C. 
medRxiv preprint doi: https://doi.org/10.1101/2021.10.28.21265616; this version posted November 8, 2021. The copyright holder for this preprint (which was not certified by peer review) is the author/funder, who has granted medRxiv a license to display the preprint in perpetuity. It is made available under a CC-BY-NC-ND 4.0 International license .

\section{Predictors of Disease Severity}

The primary outcome of severe disease (WHO COVID-19 clinical progression scale $\geq 6$ ) occurred in 102 (25\%) of 403 children (Table 3). In univariable analysis, patients with severe disease were older (median 6.69 [IQR 1.31-13.46] vs 3.21 [IQR 0.31-9.87] years, $\mathrm{p}=0.002$ ). The proportion of children with severe disease increased progressively with age, with the lowest prevalence in neonates $(8.1 \%)$ and the highest in $\geq 12$ year olds $(35.5 \%)$. Compared with previously healthy patients, those with 1 or with $\geq 2$ comorbidities were more likely to have severe disease $(19.9 \%, 31.5 \%$, and $37.3 \%$ respectively; $\mathrm{p}=0.009)$. Among individual comorbidities, obesity, non-asthma pulmonary disease, hypertension, neurological and chromosomal disorders were also risk factors, but not immunosuppression (Table 3). Shortness of breath was the only clinical presentation associated with severity with $41.5 \%$ having severe disease. Among laboratory and imaging investigations, viral coinfection, chest imaging compatible with COVID19, neutrophilia, increased CRP, and low albumin predicted a severe course. In contrast, bacterial coinfections, abnormal leukocyte or platelet count, and increased ferritin were not statistically different between mild/moderate and severe cases.

Multivariable logistic regression analysis demonstrated that obesity (OR 2.87, 95\% CI 1.19-6.93), preexisting anemia and/or hemoglobinopathy (OR 5.88, 95\% CI 1.30-26.46), underlying neurological disorder (OR 3.22, 95\% CI 1.37-7.56), shortness of breath (OR 4.37, 95\% CI 2.08-9.16), bacterial and/or viral coinfections (OR 2.26, 95\% CI 1.08-4.73), chest imaging compatible with COVID-19 (OR 2.99, 95\% CI 1.51-5.92), neutrophilia (OR 2.60, 95\% CI 1.35-5.02), and MIS-C (OR 3.86, 95\% CI 1.56-9.51) diagnosis were independent predictors of severe disease (Figure 2). In a separate model adjusting for the same covariates, we examined the effect of the number of comorbidities instead of each comorbidity individually. The presence of multiple comorbidities (OR 2.24, 95\% CI 1.04-4.81), but not of a single comorbidity (OR 1.71, 95\% CI 0.86-3.43) was a statistically significant risk factor (Figure 2). Limiting 
medRxiv preprint doi: https://doi.org/10.1101/2021.10.28.21265616; this version posted November 8, 2021. The copyright holder for this preprint (which was not certified by peer review) is the author/funder, who has granted medRxiv a license to display the preprint in perpetuity. It is made available under a CC-BY-NC-ND 4.0 International license .

the multivariable analysis to baseline characteristics identified the same risk factors as the aforementioned models which included clinical, laboratory, and outcome parameters (eTable 1).

We further analyzed the data using the secondary outcome of ICU admission and/or a WHO COVID-19 clinical progression scale of $\geq 6$. There were 128 severe cases (31.8\%) using this definition. ICU admission as a sole criterion excluded 10 patients with high flow nasal cannula and/or non-invasive ventilation who were managed outside of an ICU. Of 118 patients admitted to ICU, 26 (22\%) did not meet our primary severity definition. Contrary to our primary unadjusted analyses, single comorbidity, chromosomal disorders, and hypertension were not significantly associated with severe disease (eTable 2).

In unadjusted stratified analyses by age, risk factors for severity in children $<12$ years were nearly identical to the overall study population (eTable 3-4). However, in multivariable models, the only individual comorbidity to remain significantly associated with severity was neurologic disorders (eTable 6). Among adolescents $\geq 12$ years of age, the only comorbidity associated with severity was obesity (eTable 6). Of note, risk factors were not equally distributed between the two age groups. More adolescents had any $(66.7 \%$ vs. $40.2 \%$, p<0.001) or multiple $(25.8 \%$ vs. $16.5 \%, \mathrm{p}=0.049)$ comorbidities than younger children; obesity was markedly more common in adolescents $(40.9 \%$ vs $3.9 \%$, p<0.001).

In a sensitivity analysis, we excluded the 81 cases who met WHO MIS-C criteria. Results were very similar to the overall patient population, except that anemia and/or hemoglobinopathy and neutrophilia lost significance in the multivariable analysis (eTables 7-8). 


\section{Discussion}

In this multicenter cohort study from three countries, we identified risk factors for severe disease among children admitted to hospital for PCR-positive symptomatic SARS-CoV-2 infection. Previous studies have been either limited to administrative data, ${ }^{4,8,12}$ were smaller, ${ }^{5-7,10,11,13,14}$ or had a different scope. ${ }^{18}$ We confirmed several previously described risk factors for severity on multivariable analyses: presence of multiple comorbidities, ${ }^{4,6,9,12-15}$ obesity, ${ }^{5,8,11,14}$ neurological disorders, ${ }^{8,14}$ anemia and/or hemoglobinopathy, ${ }^{24}$ shortness of breath, ${ }^{6}$ bacterial and/or viral coinfections, ${ }^{6,15}$ chest imaging compatible with COVID-19 $9^{5,13}$, neutrophilia, ${ }^{13}$ and MIS-C diagnosis. ${ }^{5,18}$ Additionally, older age, ${ }^{4,10-12}$ hypertension, ${ }^{8}$ and chromosomal disorders, ${ }^{25}$ increased CRP, ${ }^{10,11,13,15,24}$ and low albumin were associated with higher odds of a severe course in unadjusted analyses only, but not in multivariable models, indicating that other factors may have been confounding this association or that our study was underpowered to assess less frequent comorbidities. We also found evidence that age modifies the effect of individual comorbidities, with neurological disorders strongly associated with severe disease in children under 12 years old, whereas only obesity predicted severe disease in adolescents.

Less than $5 \%$ of severe cases in our cohort were immunocompromised and impaired immunity was not associated with severity, in keeping with past pediatric studies. ${ }^{5,13,14}$ A recent study on children with cancer showed a higher rate of complications following SARS-CoV-2 infection among the severely immunocompromised. ${ }^{26}$ However, the study lacked a control group and immunocompromised children are extremely heterogeneous with multiple comorbidities complicating the interpretation. Accordingly, our data support the concept that a dysregulated rather than an insufficient immune response is a greater contributor to severe SARS-CoV-2 infection in the majority of children and adults requiring hospitalization. ${ }^{17}$ 
medRxiv preprint doi: https://doi.org/10.1101/2021.10.28.21265616; this version posted November 8, 2021. The copyright holder for this preprint

Previous studies have described a bimodal age pattern regarding severe disease, with a first peak in the very young and a second increase in adolescence mimicking global non-SARS-CoV-2-related childhood mortality. ${ }^{4,5,7,12}$ Infants in our study population were over-represented compared to the general pediatric population. For Canadian children, the proportion of infants was 4.3 times higher than its share of the population, ${ }^{27}$ suggesting a higher risk of hospitalization. It is likely that some young infants with mild symptoms were admitted for observation, especially early during the pandemic, or to rule-out serious bacterial infection. ${ }^{28}$ We did not see a higher rate of severe courses according to age, in line with other studies which restricted their analysis to hospitalized children. ${ }^{10,14,15}$ Infants typically have a significantly higher baseline all-cause morbidity and mortality than older children. ${ }^{29}$ Analyses which include all SARS-CoV-2 positive patients independent of their symptoms may mimic the baseline risk and not necessarily the infection-related complications.

Similar to other studies, we saw a higher rate of severe disease in adolescents in our univariable analysis (Table 3$),{ }^{4,10-12}$ but this was not confirmed in the multivariable models (Figure 2). This age group had a different risk profile than younger children, with obesity as the only comorbidity significantly associated with illness severity. Guzman et al. also observed that obesity was an independent risk factor for critical illness in adolescents but not younger children. ${ }^{30}$ This association more closely resembles adults, in whom metabolic risk factors are among the most important. ${ }^{31}$ The observed higher proportion of severe cases among adolescents in crude analyses could be mainly due to the markedly higher prevalence of obesity (40.9\% in adolescents vs $3.9 \%$ in younger children in our study) and other comorbidities.

Our primary outcome differed from many previous studies which defined severity as ICU admission. ${ }^{5-}$ 8,15,24 ICU admissions are simple to measure, but can be problematic as a severity outcome because of heterogeneity across study sites due to dependence on local health care delivery structures and practice. 
medRxiv preprint doi: https://doi.org/10.1101/2021.10.28.21265616; this version posted November 8, 2021. The copyright holder for this preprint

In addition, patients with some comorbidities or within certain age categories may be admitted to ICU mainly for monitoring or for treatment of a condition independent of the severity of the current illness, e.g. patients with tracheostomy or type-1 diabetes mellitus. ${ }^{32}$ Therefore, we used the more objective WHO COVID-19 clinical progression scale which is based on the need for mechanical or medical support of vital functions, ${ }^{20}$ similar to the definition used by Ouldali et al. ${ }^{10}$ Our comparative analysis of two different severity criteria shows that the effect of several important risk factors would have been obscured using ICU admission alone to define severity.

We decided to include all hospitalized symptomatic patients with positive SARS-CoV-2 PCR, independent of the diagnosis of MIS-C. Although the pathophysiology is different, ${ }^{17}$ it is frequently impossible to distinguish severe acute SARS-CoV-2 infections from PCR-positive MIS-C and both can be present at the same time. ${ }^{18}$ In a sensitivity analysis, risk factors for a severe course after exclusion of MIS-C cases were very similar to the primary analysis that included MIS-C. Thus, the strict separation of acute COVID-19 and early PCR-positive MIS-C may be an oversimplification. Moreover, treatment regimens for both conditions can overlap. Late, and typically PCR-negative, MIS-C has been shown to have different severity risk factors. ${ }^{5,13,18}$ By requiring patients to be PCR-positive, two-thirds of MIS-C patients were excluded. The analysis of all MIS-C patients from the PICNIC cohort is being reported separately. ${ }^{33}$

Our study has limitations. First, reporting may not have been uniform across centers despite the use of a study protocol and a standardized data capture tool. This includes but is not limited to the interpretation of chest radiographs, definition of obesity, and the severity of comorbidities. Also, the respective comorbidities can represent a heterogeneous group of diseases with different etiologies. Second, despite being one of the largest pediatric cohort studies with more than 100 severe cases, the numbers of some individual comorbidities are small. This might overestimate or underestimate the impact of infrequent 
medRxiv preprint doi: https://doi.org/10.1101/2021.10.28.21265616; this version posted November 8, 2021. The copyright holder for this preprint

comorbidities such as anemia and/or hemoglobinopathy, chromosomal, or cardiac disorders. Third, laboratory investigations were not systematically performed. Complete blood counts, CRP, and albumin values were missing in $4.2 \%, 15 \%$, and $67 \%$, respectively. We therefore could not assess the latter in multivariable models. Moreover, laboratory investigations were done at the clinicians' discretion, not at set time points during the illness. Other parameters previously described as risk factors could not be evaluated. This includes ethnicity ${ }^{4,7,9,12}$ which was not readily accessible from hospital records. In addition, viral sequencing data was not available, accordingly we cannot evaluate the impact of different SARS-CoV-2 variants. Fourth, indications for testing for SARS-CoV-2 likely varied by center and over time, which might have affected the clinical spectrum of included patients. However, since we analyzed symptomatic hospitalized patients admitted for SARS-CoV-2 infection or PCR-positive MIS-C in centers with availability of SARS-CoV-2 PCR tests, we do not expect this to bias our results. Fifth, our study was not population-based. Most participating hospitals are referral centers so milder hospitalized cases might have been missed and this might overestimate the rate of severe courses. In addition, there were only two hospitals from Costa Rica and Iran, representing one-third of the total sample size; they may not be representative of middle-income countries in general.

A major strength of our study includes its multicenter, multi-national design covering the first 15 months of the COVID-19 pandemic. The patient population of symptomatic children hospitalized for PCRconfirmed SARS-CoV-2 is well-defined and reduces potential biases from including incidental detections of SARS-CoV-2. Finally, this study represents one of the largest yet comprehensive datasets with over 100 severe cases, thereby allowing us to identify differences in risk factor profiles across age groups.

In conclusion, we identified several independent risk factors for severe disease in children hospitalized for symptomatic PCR-positive SARS-CoV-2 infection, namely the presence of multiple comorbidities, obesity, anemia and/or hemoglobinopathy, neurological disorder, shortness of breath, bacterial and/or 
medRxiv preprint doi: https://doi.org/10.1101/2021.10.28.21265616; this version posted November 8, 2021. The copyright holder for this preprint (which was not certified by peer review) is the author/funder, who has granted medRxiv a license to display the preprint in perpetuity. It is made available under a CC-BY-NC-ND 4.0 International license.

viral coinfections, chest imaging compatible with COVID-19, neutrophilia, and MIS-C diagnosis. Based on our analysis, age was not an independent risk factor, but the apparent increased risk in adolescents is mainly secondary to the presence of age-specific comorbidities. Furthermore, age appears to modify the effect of specific comorbidities such as obesity. Improved understanding of pediatric risk factors for severe SARS-CoV-2 infection among children requiring hospitalization can guide management and refine risk-benefit analyses of pediatric vaccination programs against SARS-CoV-2. 
medRxiv preprint doi: https://doi.org/10.1101/2021.10.28.21265616; this version posted November 8, 2021. The copyright holder for this preprint

(which was not certified by peer review) is the author/funder, who has granted medRxiv a license to display the preprint in perpetuity.

It is made available under a CC-BY-NC-ND 4.0 International license .

\section{Acknowledgements}

We thank Dr. Joanna Merckx for her thoughtful review of an earlier version of this manuscript.

\section{Author contributions}

The study was conceived by Joan Robinson, Michelle Barton-Forbes and Jesse Papenburg, and supervised by Joan Robinson and Jesse Papenburg. Analysis was conducted by Chelsea Caya and Tilmann Schober. Tilmann Schober wrote the first draft of the manuscript. All authors contributed to data collection and interpretation, reviewed the manuscript critically for important intellectual content, gave final approval of the version to be published and agreed to be accountable for all aspects of the work.

\section{Data sharing statement}

The corresponding authors will consider data sharing requests that are accompanied by a study protocol and approval by an independent research ethics board.

\section{Funding sources}

None 
medRxiv preprint doi: https://doi.org/10.1101/2021.10.28.21265616; this version posted November 8, 2021. The copyright holder for this preprint (which was not certified by peer review) is the author/funder, who has granted medRxiv a license to display the preprint in perpetuity. It is made available under a CC-BY-NC-ND 4.0 International license.

\section{Declaration of interests}

Manish Sadarangani has been an investigator on projects funded by GlaxoSmithKline, Merck, Pfizer, Sanofi-Pasteur, Seqirus, Symvivo and VBI Vaccines. All funds have been paid to his institute, and he has not received any personal payments. Jesse Papenburg reports grants to his institution from MedImmune, Sanofi Pasteur and AbbVie, and personal fees from AbbVie, all outside of the submitted work. Shaun K Morris has received honoraria for lectures from GlaxoSmithKline and was a member of an ad hoc advisory board for Pfizer Canada, both outside of the submitted work. 
medRxiv preprint doi: https://doi.org/10.1101/2021.10.28.21265616; this version posted November 8, 2021. The copyright holder for this preprint (which was not certified by peer review) is the author/funder, who has granted medRxiv a license to display the preprint in perpetuity. It is made available under a CC-BY-NC-ND 4.0 International license .

\section{References}

1. Delahoy MJ, Ujamaa D, Whitaker M, et al. Hospitalizations Associated with COVID-19 Among Children and Adolescents - COVID-NET, 14 States, March 1, 2020-August 14, 2021. MMWR Morb Mortal Wkly Rep. 2021;70(36):1255-1260.

2. Public Health England. JCVI issues updated advice on COVID-19 vaccination of children aged 12 to 15. 2021; https://www.gov.uk/government/news/jcvi-issues-updated-advice-on-covid-19vaccination-of-children-aged-12-to-15. Accessed 09/03/2021).

3. WHO. COVID-19 Vaccines Advice. 2021; https://www.who.int/emergencies/diseases/novelcoronavirus-2019/covid-19-vaccines/advice. Accessed 29/09/2021).

4. Bixler D, Miller AD, Mattison CP, et al. SARS-CoV-2-Associated Deaths Among Persons Aged <21 Years - United States, February 12-July 31, 2020. MMWR Morb Mortal Wkly Rep. 2020;69(37):1324-1329.

5. Fernandes DM, Oliveira CR, Guerguis S, et al. Severe Acute Respiratory Syndrome Coronavirus 2 Clinical Syndromes and Predictors of Disease Severity in Hospitalized Children and Youth. J Pediatr. 2021;230:23-31 e10.

6. Gotzinger F, Santiago-Garcia B, Noguera-Julian A, et al. COVID-19 in children and adolescents in Europe: a multinational, multicentre cohort study. Lancet Child Adolesc Health. 2020;4(9):653-661.

7. Graff K, Smith C, Silveira L, et al. Risk Factors for Severe COVID-19 in Children. Pediatr Infect Dis J. 2021;40(4):e137-e145.

8. Kompaniyets L, Agathis NT, Nelson JM, et al. Underlying Medical Conditions Associated With Severe COVID-19 Illness Among Children. JAMA Netw Open. 2021;4(6):e2111182.

9. Moreira A, Chorath K, Rajasekaran K, Burmeister F, Ahmed M, Moreira A. Demographic predictors of hospitalization and mortality in US children with COVID-19. Eur J Pediatr. 2021;180(5):1659-1663.

10. Ouldali N, Yang DD, Madhi F, et al. Factors Associated With Severe SARS-CoV-2 Infection. Pediatrics. 2021;147(3).

11. Zachariah P, Johnson CL, Halabi KC, et al. Epidemiology, Clinical Features, and Disease Severity in Patients With Coronavirus Disease 2019 (COVID-19) in a Children's Hospital in New York City, New York. JAMA Pediatr. 2020;174(10):e202430.

12. Oliveira EA, Colosimo EA, Simoes ESAC, et al. Clinical characteristics and risk factors for death among hospitalised children and adolescents with COVID-19 in Brazil: an analysis of a nationwide database. Lancet Child Adolesc Health. 2021;5(8):559-568.

13. Swann OV, Holden KA, Turtle L, et al. Clinical characteristics of children and young people admitted to hospital with covid-19 in United Kingdom: prospective multicentre observational cohort study. BMJ. 2020;370:m3249.

14. Drouin O HC, Farrar, DS, et al. Characteristics of children admitted to hospital with acute SARS-CoV-2 infection in Canada in 2020. CMAJ. 2021;193(38).

15. Garazzino S, Lo Vecchio A, Pierantoni L, et al. Epidemiology, Clinical Features and Prognostic Factors of Pediatric SARS-CoV-2 Infection: Results From an Italian Multicenter Study. Front Pediatr. 2021;9:649358.

16. Gates M PJ, Wingert A, Guitard S, Rahman S, Zakher B, Gates A, Hartling L. Risk factors associated with severe outcomes of COVID-19: An updated rapid review to inform national guidance on vaccine prioritization in Canada. medRxiv. 2021.

17. Brodin P. Immune determinants of COVID-19 disease presentation and severity. Nat Med. 2021;27(1):28-33. 
medRxiv preprint doi: https://doi.org/10.1101/2021.10.28.21265616; this version posted November 8, 2021. The copyright holder for this preprint (which was not certified by peer review) is the author/funder, who has granted medRxiv a license to display the preprint in perpetuity. It is made available under a CC-BY-NC-ND 4.0 International license .

18. Feldstein LR, Tenforde MW, Friedman KG, et al. Characteristics and Outcomes of US Children and Adolescents With Multisystem Inflammatory Syndrome in Children (MIS-C) Compared With Severe Acute COVID-19. JAMA. 2021;325(11):1074-1087.

19. von Elm E, Altman DG, Egger M, et al. The Strengthening the Reporting of Observational Studies in Epidemiology (STROBE) statement: guidelines for reporting observational studies. Lancet. 2007;370(9596):1453-1457.

20. WHO Working Group on the Clinical Characterisation and Management of COVID-19 infection. A minimal common outcome measure set for COVID-19 clinical research. Lancet Infect Dis. 2020;20(8):e192-e197.

21. National Advisory Committee on Immunization. Canadian Immunization Guide Chapter on Influenza and Statement on Seasonal Influenza Vaccine for 2020-2021. In: Canada PHAo, ed2020.

22. Orkin N, Nathan D, Ginsburg D. Nathan \& Oski's Hematology of Infancy and Childhood. 7th ed. Philadelphia 2009.

23. WHO. Multisystem inflammatory syndrome in children and adolescents temporally related to COVID-19. 2020. https://www.who.int/news-room/commentaries/detail/multisysteminflammatory-syndrome-in-children-and-adolescents-with-covid-19. Accessed 10/04/2021).

24. Al Yazidi LS, Al Hinai Z, Al Waili B, et al. Epidemiology, characteristics and outcome of children hospitalized with COVID-19 in Oman: A multicenter cohort study. Int J Infect Dis. 2021;104:655-660.

25. Malle L, Gao C, Hur C, et al. Individuals with Down syndrome hospitalized with COVID-19 have more severe disease. Genet Med. 2021;23(3):576-580.

26. Mukkada S, Bhakta N, Chantada GL, et al. Global characteristics and outcomes of SARS-CoV2 infection in children and adolescents with cancer (GRCCC): a cohort study. Lancet Oncol. 2021;22(10):1416-1426.

27. Statistics Canada. Table 17-10-0005-01 Population estimates on July 1st, by age and sex. https://www150.statcan.gc.ca/t1/tbl1/en/tv.action?pid=1710000501. Accessed 09/28/2021).

28. Burstein B, Anderson G, Yannopoulos A. Prevalence of Serious Bacterial Infections Among Febrile Infants 90 Days or Younger in a Canadian Urban Pediatric Emergency Department During the COVID-19 Pandemic. JAMA Netw Open. 2021;4(7):e2116919.

29. United Nations Interagency Group for Child Mortality Estimation. Levels \& Trends in Child Mortality: Report 2020, Estimates developed by the United Nations Interagency Group for Child Mortality Estimation. New York2020.

30. Guzman BV, Elbel B, Jay M, Messito MJ, Curado S. Age-dependent association of obesity with COVID-19 severity in paediatric patients. Pediatr Obes. 2021:e12856.

31. Williamson EJ, Walker AJ, Bhaskaran K, et al. Factors associated with COVID-19-related death using OpenSAFELY. Nature. 2020;584(7821):430-436.

32. Schuster JE, de St Maurice A. COVID-19 in Children-Not Just Little Adults. JAMA Netw Open. 2021;4(6):e2111441.

33. Merckx J, Cooke S, Tal TE, et al. Multicenter cohort study of multisystem inflammatory syndrome in children (MIS-C). medRxiv. 2021. 
medRxiv preprint doi: https://doi.org/10.1101/2021.10.28.21265616; this version posted November 8, 2021. The copyright holder for this preprint (which was not certified by peer review) is the author/funder, who has granted medRxiv a license to display the preprint in perpetuity. It is made available under a CC-BY-NC-ND 4.0 International license.

Figure 1. Flow chart of hospitalized children < 18 years of age reported to the PICNIC study between February 1, 2020 and May 31, 2021 with a diagnosis of SARS-CoV-2 infection

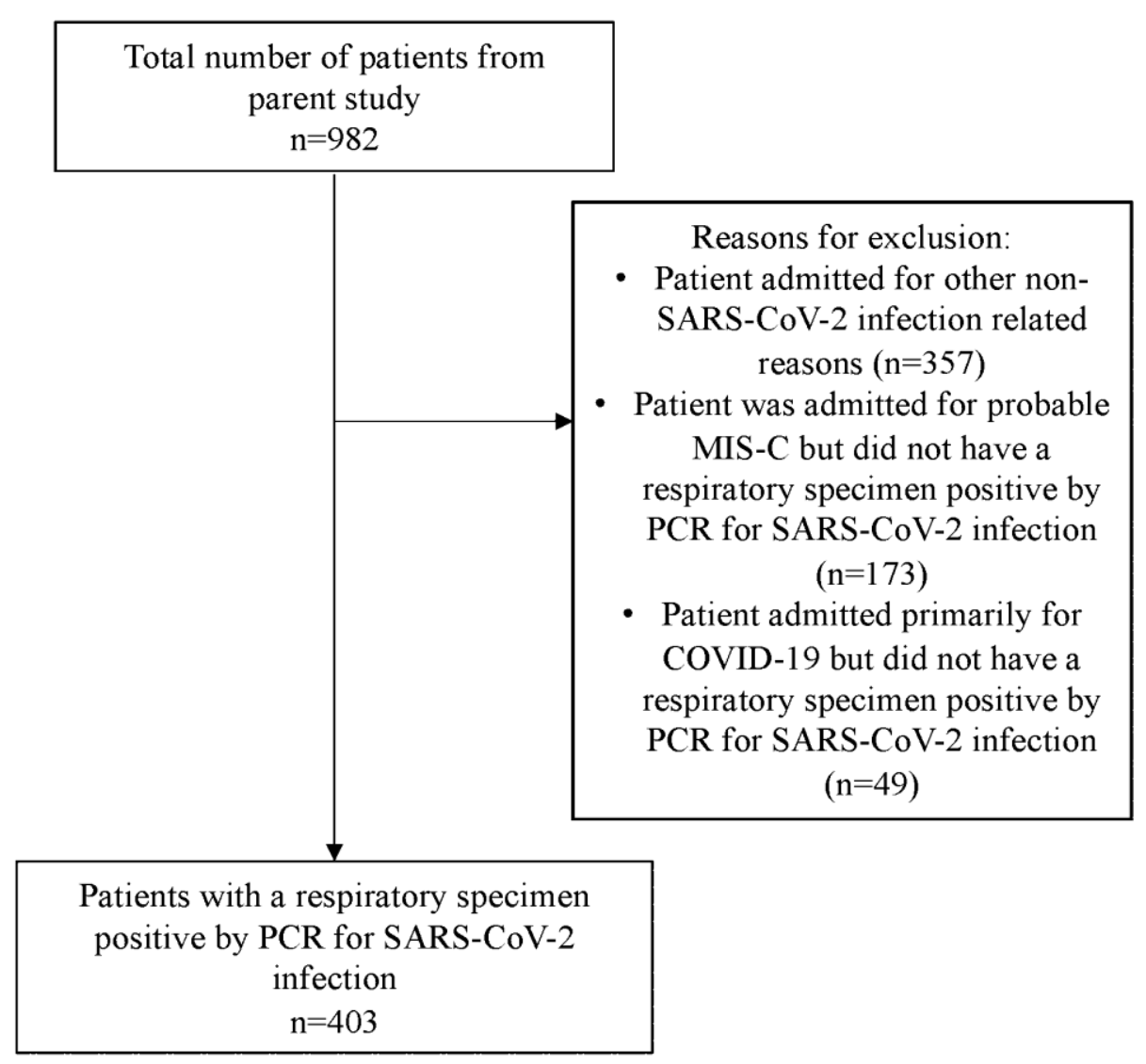


medRxiv preprint doi: https://doi.org/10.1101/2021.10.28.21265616; this version posted November 8, 2021. The copyright holder for this preprint (which was not certified by peer review) is the author/funder, who has granted medRxiv a license to display the preprint in perpetuity.

It is made available under a CC-BY-NC-ND 4.0 International license.

Figure 2 Multivariable logistic regression models for factors associated with severe PCR-positive SARS-CoV-2 infection (WHO COVID-19 clinical progression scale of $\geq 6$ )

A

\begin{tabular}{|l|l|}
\hline Covariates & aOR $(95 \%$ CI $)$ \\
\hline$<1$ year & Reference \\
\hline $1-4$ years & $0.83(0.35-1.96)$ \\
\hline $5-11$ years & $0.49(0.17-1.36)$ \\
\hline$\geq 12$ years & $0.59(0.23-1.49)$ \\
\hline Obesity & $2.87(1.19-6.93)$ \\
\hline Non-asthma pulmonary disorders & $0.74(0.21-2.62)$ \\
\hline Anemia and/or hemoglobinopathy & $5.88(1.30-26.46)$ \\
\hline Neurological disorders & $3.22(1.37-7.56)$ \\
\hline Hypertension & $1.83(0.27-12.53)$ \\
\hline Chromosomal disorders & $3.43(0.45-25.91)$ \\
\hline Bacterial or viral coinfection & $2.26(1.08-4.73)$ \\
\hline No chest imaging done & $0.26(0.06-1.24)$ \\
\hline CXR and/or CT normal or unrelated to COVID-19 & Reference \\
\hline CXR or CT abnormalities compatible with COVID-19 & $2.99(1.51-5.92)$ \\
\hline Neutrophilia & $2.60(1.35-5.02)$ \\
\hline Shortness of breath & $4.37(2.08-9.16)$ \\
\hline MIS-C diagnosis & $3.86(1.56-9.51)$ \\
\hline
\end{tabular}

B

\begin{tabular}{|c|c|}
\hline Covariates & aOR $(95 \% \mathrm{CI})$ \\
\hline$<1$ year & Reference \\
\hline $1-4$ years & $0.83(0.35-1.95)$ \\
\hline $5-11$ years & $0.66(0.25-1.74)$ \\
\hline$\geq 12$ years & $0.83(0.35-1.96)$ \\
\hline No comorbidity & Reference \\
\hline 1 comorbidity & $1.71(0.86-3.43)$ \\
\hline Multiple $(\geq 2)$ comorbidities & $2.24(1.04-4.81)$ \\
\hline Bacterial or viral coinfections & $1.89(0.92-3.87)$ \\
\hline No chest imaging done & $0.27(0.06-1.24)$ \\
\hline CXR and/or CT normal or unrelated to COVD-19 & Reference \\
\hline CXR or CT abnormalities compatible with COVID- 19 & $3.08(1.59-5.94)$ \\
\hline Neutrophilia & $2.39(1.27-4.50)$ \\
\hline Shortness of breath & $4.08(2.06-8.09)$ \\
\hline MIS-C diagnosis & $3.41(1.40-8.33)$ \\
\hline
\end{tabular}
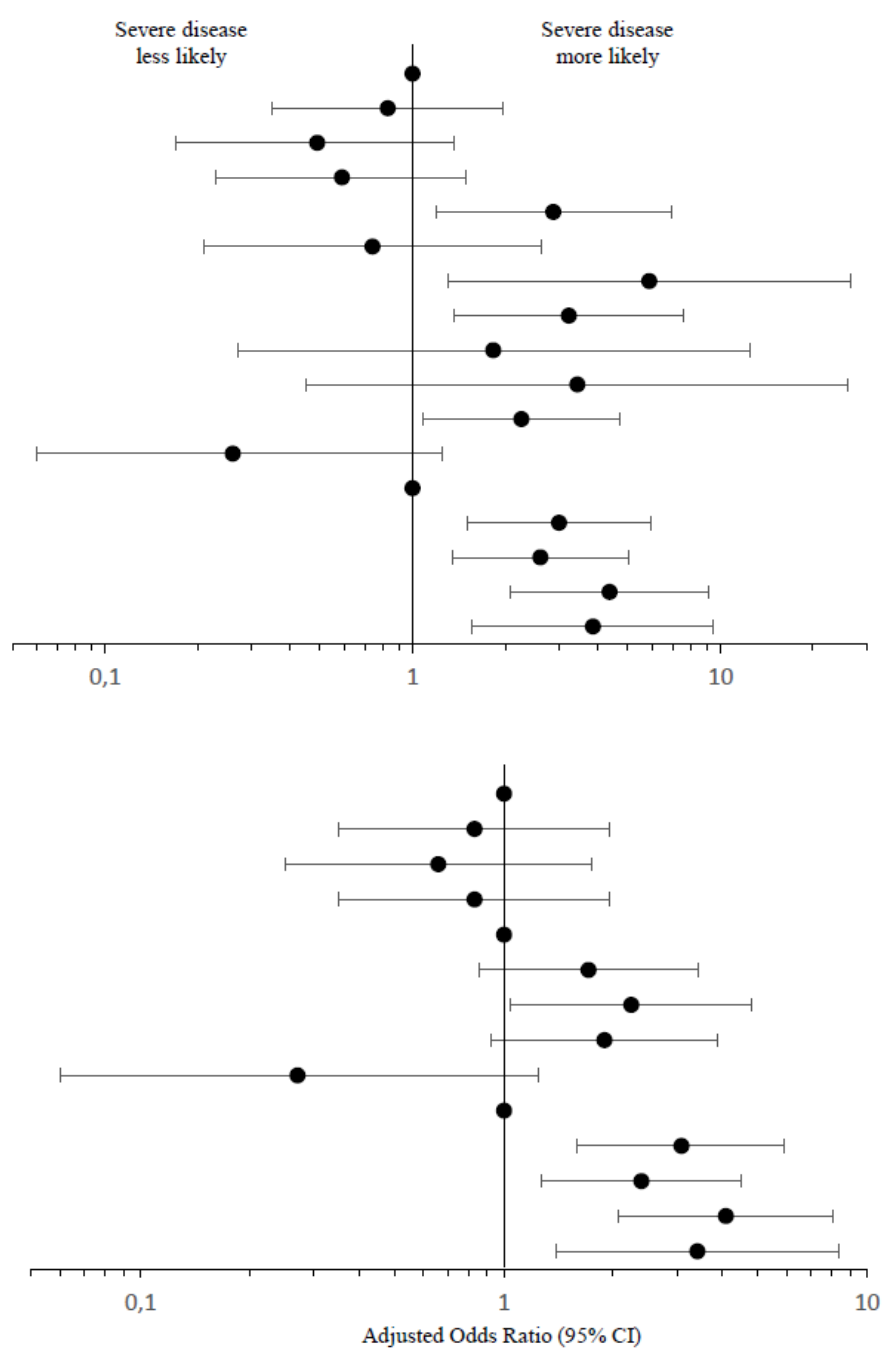

Legend: The model in Panel A evaluated individual comorbidities whereas the model in Panel B evaluated the number of comorbidities, as risk factors for disease severity.

aOR adjusted odds ratio; CT computed tomography; CXR chest x-ray; MIS-C multisystem inflammatory syndrome in children 
medRxiv preprint doi: https://doi.org/10.1101/2021.10.28.21265616; this version posted November 8, 2021. The copyright holder for this preprint (which was not certified by peer review) is the author/funder, who has granted medRxiv a license to display the preprint in perpetuity. It is made available under a CC-BY-NC-ND 4.0 International license .

Table 1. Baseline characteristics of patients with PCR-positive SARS-CoV-2 infection ( $\mathrm{n}=403)$ according to country of origin

\begin{tabular}{|c|c|c|c|c|}
\hline & $\begin{array}{c}\text { Canada } \\
\mathrm{N}=266(\%)\end{array}$ & $\begin{array}{l}\text { Costa Rica } \\
\mathrm{N}=107(\%)\end{array}$ & $\begin{array}{c}\text { Iran } \\
\mathbf{N}=\mathbf{3 0}(\%)\end{array}$ & $\begin{array}{c}\text { Total } \\
\mathrm{N}=\mathbf{4 0 3}(\%)\end{array}$ \\
\hline \multicolumn{5}{|l|}{ Demographics } \\
\hline Median Age in years (IQR) $^{1}$ & $5.82(0.84-14.27)$ & $2.19(0.47-5.94)$ & $2.04(0.67-5.96)$ & $3.78(0.53-10.77)$ \\
\hline Age $\leq 30$ days & $30(11.3 \%)$ & $7(6.5 \%)$ & 0 & $37(9.2 \%)$ \\
\hline \multicolumn{5}{|l|}{ Age category ${ }^{1}$} \\
\hline$<1$ year & $67(25.3 \%)$ & $36(34.0 \%)$ & $10(33.3 \%)$ & $113(28.2 \%)$ \\
\hline $1-4$ years & $58(21.9 \%)$ & $40(37.7 \%)$ & $8(26.7 \%)$ & $106(26.4 \%)$ \\
\hline 5-11 years & $53(20.0 \%)$ & $24(22.6 \%)$ & $12(40.0 \%)$ & $89(22.2 \%)$ \\
\hline$\geq 12$ years & $87(32.8 \%)$ & $6(5.7 \%)$ & 0 & $93(23.2 \%)$ \\
\hline Male sex & $147(55.3 \%)$ & $64(59.8 \%)$ & $16(53.3 \%)$ & $227(56.3 \%)$ \\
\hline \multicolumn{5}{|l|}{ Admission period } \\
\hline Prior to July 1, 2020 & $12(4.5 \%)$ & 0 & $7(23.3 \%)$ & $19(4.7 \%)$ \\
\hline $\begin{array}{l}\text { Between July 1, } 2020 \text { to } \\
\text { Dec } 31,2020\end{array}$ & $77(28.9 \%)$ & $57(53.3 \%)$ & $17(56.7 \%)$ & $151(37.5 \%)$ \\
\hline $\begin{array}{l}\text { Between Jan 1, } 2021 \text { to } \\
\text { May 31, } 2021\end{array}$ & $177(66.5 \%)$ & $50(46.7 \%)$ & $6(20.0 \%)$ & $233(57.8 \%)$ \\
\hline \multicolumn{5}{|l|}{ Number of comorbidities } \\
\hline None & $140(52.6 \%)$ & $61(57.0 \%)$ & $15(50.0 \%)$ & $216(53.6 \%)$ \\
\hline At least 1 comorbidity & $126(47.4 \%)$ & $46(43.0 \%)$ & $15(50.0 \%)$ & $187(46.4 \%)$ \\
\hline 1 comorbidity & $68(25.6 \%)$ & $31(29.0 \%)$ & $13(43.3 \%)$ & $112(27.8 \%)$ \\
\hline $\begin{array}{l}\text { Multiple }(\geq 2) \\
\text { comorbidities }\end{array}$ & $58(21.8 \%)$ & $15(14.0 \%)$ & $2(6.7 \%)$ & $75(18.6 \%)$ \\
\hline \multicolumn{5}{|l|}{ Individual comorbidities $^{2}$} \\
\hline Obesity & $44(16.5 \%)$ & $5(4.7 \%)$ & $1(3.3 \%)$ & $50(12.4 \%)$ \\
\hline Pulmonary disorders & $32(12.0 \%)$ & $20(18.7 \%)$ & $2(6.7 \%)$ & $54(13.4 \%)$ \\
\hline $\begin{array}{l}\text { Non-asthma } \\
\text { pulmonary disorders }{ }^{3}\end{array}$ & $16(6.0 \%)$ & $4(3.7 \%)$ & $2(6.7 \%)$ & $22(5.4 \%)$ \\
\hline Asthma & $16(6.0 \%)$ & $16(14.9 \%)$ & 0 & $32(7.9 \%)$ \\
\hline $\begin{array}{l}\text { Prematurity ( }<37 \text { weeks } \\
\text { gestational age) }\end{array}$ & $26(9.8 \%)$ & $4(3.7 \%)$ & 0 & $30(7.4 \%)$ \\
\hline Immunosuppression & $16(6.0 \%)$ & $11(10.3 \%)$ & $4(13.3 \%)$ & $31(7.7 \%)$ \\
\hline Malignancy $^{4}$ & $4(1.5 \%)$ & $8(7.5 \%)$ & $4(13.3 \%)$ & $16(4.0 \%)$ \\
\hline $\begin{array}{l}\text { Anemia and/or } \\
\text { hemoglobinopathy }{ }^{5}\end{array}$ & $13(4.9 \%)$ & 0 & 0 & $13(3.2 \%)$ \\
\hline Sick cell anemia & $6(2.2 \%)$ & 0 & 0 & $6(1.5 \%)$ \\
\hline Neurological disorders $^{6}$ & $40(15.0 \%)$ & $13(12.1 \%)$ & $3(10.0 \%)$ & $56(13.9 \%)$ \\
\hline Cardiac disorders & $11(4.1 \%)$ & $6(5.6 \%)$ & $2(6.7 \%)$ & $19(4.7 \%)$ \\
\hline Metabolic disorders & $9(3.4 \%)$ & $2(1.9 \%)$ & $1(3.3 \%)$ & $12(3.0 \%)$ \\
\hline Diabetes mellitus & $4(1.5 \%)$ & 0 & $1(3.3 \%)$ & $5(1.2 \%)$ \\
\hline Renal disorders & $8(3.0 \%)$ & $3(2.8 \%)$ & $3(10.0 \%)$ & $14(3.5 \%)$ \\
\hline Hypertension & $6(2.2 \%)$ & $3(2.8 \%)$ & 0 & $9(2.2 \%)$ \\
\hline Chromosomal disorders $^{7}$ & $6(2.2 \%)$ & $2(1.9 \%)$ & 0 & $8(2.0 \%)$ \\
\hline Other $^{8}$ & $18(6.8 \%)$ & $5(4.7 \%)$ & $2(6.7 \%)$ & $25(6.2 \%)$ \\
\hline
\end{tabular}

IQR interquartile range; MIS-C multisystem inflammatory syndrome in children 
${ }^{1}$ One child from Canada and one child from Costa Rica are missing date of birth.

${ }^{2}$ Children are listed more than once if they had more than one comorbidity.

${ }^{3}$ Additional information is available for $14 / 22$ patients: obstructive sleep apnea $(n=5)$; bronchopulmonary dysplasia $(n=3)$; pulmonary hypertension $(n=2)$; cystic fibrosis $(n=1)$; chronic aspiration pneumonia $(n=1)$; subglottic stenosis $(n=1)$; PierreRobin anomaly $(n=1)$

${ }^{4}$ Malignancy consists of the following: acute lymphoblastic leukemia $(n=11)$; neuroblastoma $(n=2)$; lymphoma $(n=1)$; rhabdomyosarcoma $(\mathrm{n}=1)$; and osteosarcoma $(\mathrm{n}=1)$

${ }^{5}$ Anemia and/or hemoglobinopathy consists of the following: sickle cell disease $(n=6)$; Glucose-6-phosphate dehydrogenase deficiency $(n=2)$; anemia of chronic disease $(n=2)$; ovalocytosis $(n=1)$; pancytopenia of unknown etiology $(n=1)$; iron deficient anemia $(n=1)$

${ }^{6}$ Additional information is available for 47/56 patients: syndromic condition with global developmental delay (GDD) $(n=19)$; autism and/or GDD of unexplained etiology $(n=10)$; cerebral palsy $(n=7)$; muscular dystrophy $(n=3)$; hydrocephalus $(n=2)$; congenital microcephaly $(n=2)$; brain tumor $(n=1)$; focal cortical dysplasia $(n=1)$; encephalopathy $(n=1)$; epilepsy $(\mathrm{n}=1)$

${ }^{7}$ Additional information is available for 7/8 patients: Trisomy $21(\mathrm{n}=3)$; unbalanced translocation $(\mathrm{n}=2)$; Prader-Willi syndrome $(n=1)$; Miller-Dieker syndrome $(n=1)$

${ }^{8}$ Other consists of the following: gastrostomy $(n=12)$; liver transplantation $(n=2)$; celiac disease $(n=1)$; Crohn's disease $(n=1)$ failure to thrive $(n=1)$; inflammatory bowel disease $(n=1)$; inflammatory bowel disease and Hirschsprung disease $(n=1)$; unclear liver disease $(n=1)$; esophageal atresia $(n=1)$; scoliosis $(n=2)$; liver cirrhosis \& cholestasis $(n=1)$; Glanzmann thrombasthenia $(n=1)$ 
medRxiv preprint doi: https://doi.org/10.1101/2021.10.28.21265616; this version posted November 8, 2021. The copyright holder for this preprint (which was not certified by peer review) is the author/funder, who has granted medRxiv a license to display the preprint in perpetuity. It is made available under a CC-BY-NC-ND 4.0 International license .

Table 2. Clinical characteristics, investigations, treatments and outcomes of patients with severe PCRpositive SARS-CoV-2 infection ( $\mathrm{n}=403)$ according to country of origin

\begin{tabular}{|c|c|c|c|c|}
\hline & $\begin{array}{c}\text { Canada } \\
\mathrm{N}=266(\%)\end{array}$ & $\begin{array}{c}\text { Costa Rica } \\
\mathrm{N}=107(\%)\end{array}$ & $\begin{array}{c}\text { Iran } \\
\mathrm{N}=\mathbf{3 0}(\%)\end{array}$ & $\begin{array}{c}\text { Total } \\
\mathrm{N}=\mathbf{4 0 3}(\%)\end{array}$ \\
\hline \multicolumn{5}{|l|}{ Clinical Features } \\
\hline Fever prior to or during admission ${ }^{1}$ & $205(82.3 \%)$ & $71(78.0 \%)$ & $26(92.8 \%)$ & $302(82.1 \%)$ \\
\hline Cough & $136(51.1 \%)$ & $54(50.5 \%)$ & $18(60.0 \%)$ & $208(51.6 \%)$ \\
\hline Shortness of breath & $125(47.0 \%)$ & $55(51.4 \%)$ & $8(26.7 \%)$ & $188(46.7 \%)$ \\
\hline Vomiting & $91(34.2 \%)$ & $22(20.6 \%)$ & $14(46.7 \%)$ & $127(31.5 \%)$ \\
\hline Rhinitis & $66(24.8 \%)$ & $49(45.8 \%)$ & $10(33.3 \%)$ & $125(31.0 \%)$ \\
\hline Diarrhea & $70(26.3 \%)$ & $31(29.0 \%)$ & $14(46.7 \%)$ & $115(28.5 \%)$ \\
\hline Abdominal pain & $67(25.2 \%)$ & $26(24.3 \%)$ & $15(50.0 \%)$ & $108(26.8 \%)$ \\
\hline Headache & $47(17.7 \%)$ & $19(17.8 \%)$ & $6(20.0 \%)$ & $72(17.9 \%)$ \\
\hline Rash & $42(15.8 \%)$ & $24(22.4 \%)$ & $3(10.0 \%)$ & $69(17.1 \%)$ \\
\hline Conjunctivitis & $46(17.3 \%)$ & $21(19.6 \%)$ & $1(3.3 \%)$ & $68(16.9 \%)$ \\
\hline Myalgia & $30(11.3 \%)$ & $12(11.2 \%)$ & $18(60.0 \%)$ & $60(14.9 \%)$ \\
\hline Pharyngitis & $32(12.0 \%)$ & $15(14.0 \%)$ & $13(43.3 \%)$ & $60(14.9 \%)$ \\
\hline Wheeze & $16(6.0 \%)$ & $26(24.3 \%)$ & $12(40.0 \%)$ & $54(13.4 \%)$ \\
\hline Chest pain & $32(12.0 \%)$ & $3(2.8 \%)$ & $4(13.3 \%)$ & $39(9.7 \%)$ \\
\hline Cracked lips & $22(8.3 \%)$ & $16(14.9 \%)$ & 0 & $38(9.4 \%)$ \\
\hline Edema of hands and feet & $14(5.3 \%)$ & $12(11.2 \%)$ & $1(3.3 \%)$ & $27(6.7 \%)$ \\
\hline Anosmia & $10(3.7 \%)$ & $2(1.9 \%)$ & 0 & $12(3.0 \%)$ \\
\hline Seizures & $6(2.2 \%)$ & $3(2.8 \%)$ & $2(6.7 \%)$ & $11(2.7 \%)$ \\
\hline \multicolumn{5}{|l|}{ Coinfections } \\
\hline Bacterial (positive cultures) $^{2}$ & $14(5.3 \%)$ & $7(6.5 \%)$ & $3(10.0 \%)$ & $24(5.9 \%)$ \\
\hline Viral & $7(2.6 \%)$ & $25(23.4 \%)$ & 0 & $32(7.9 \%)$ \\
\hline Bacterial and/or viral & $21(7.9 \%)$ & $30(28.0 \%)$ & $3(10.0 \%)$ & $54(13.4 \%)$ \\
\hline \multicolumn{5}{|l|}{ Investigations } \\
\hline Chest imaging performed $^{3}$ & $200(75.2 \%)$ & $82(76.6 \%)$ & $30(100.0 \%)$ & $312(77.4 \%)$ \\
\hline $\begin{array}{l}\text { CXR and/or CT chest normal or had } \\
\text { findings unrelated to COVID-19 }\end{array}$ & $60(22.5 \%)$ & $45(42.0 \%)$ & $16(53.3 \%)$ & $121(30.0 \%)$ \\
\hline $\begin{array}{l}\text { CXR and/or CT chest abnormalities } \\
\text { compatible with COVID-19 }\end{array}$ & $140(52.6 \%)$ & $37(34.6 \%)$ & $14(46.7 \%)$ & $191(47.4 \%)$ \\
\hline \multicolumn{5}{|l|}{ Laboratory investigations ${ }^{4}$} \\
\hline Leukopenia $\left(<4 \times 10^{9} / \mathrm{L}\right)^{5}$ & $43(17.1 \%)$ & $12(11.5 \%)$ & $4(13.3 \%)$ & $59(15.3 \%)$ \\
\hline Leukocytosis $\left(>15 \times 10^{9} / \mathrm{L}\right)^{5}$ & $20(7.9 \%)$ & $21(20.2 \%)$ & $6(20.0 \%)$ & $47(12.2 \%)$ \\
\hline Neutropenia $\left(<1.5 \times 10^{9} / \mathrm{L}\right)^{6}$ & $53(21.4 \%)$ & $27(26.0 \%)$ & $8(26.7 \%)$ & $88(23.0 \%)$ \\
\hline Neutrophilia $^{6}$ & $73(29.4 \%)$ & $37(35.6 \%)$ & $10(33.3 \%)$ & $120(31.4 \%)$ \\
\hline $\begin{array}{l}\text { Thrombocytopenia } \\
\left(<100 \times 10^{9} / \mathrm{L}\right)^{7}\end{array}$ & $27(10.8 \%)$ & $12(11.5 \%)$ & $5(16.7 \%)$ & $44(11.4 \%)$ \\
\hline Thrombocytosis $\left(>450 \times 10^{9} / \mathrm{L}\right)^{7}$ & $47(18.7 \%)$ & $29(27.9 \%)$ & $10(33.3 \%)$ & $86(22.3 \%)$ \\
\hline $\mathrm{CRP}>50(\mathrm{mg} / \mathrm{L})^{8}$ & $87(38.7 \%)$ & $22(25.0 \%)$ & $10(33.3 \%)$ & $119(34.7 \%)$ \\
\hline Ferritin $>500(\mathrm{mcg} / \mathrm{L})^{9}$ & $37(28.2 \%)$ & $12(37.5 \%)$ & $6(30.0 \%)$ & $55(30.0 \%)$ \\
\hline Albumin $<29(\mathrm{~g} / \mathrm{L})^{10}$ & $34(45.9 \%)$ & $10(21.7 \%)$ & $2(16.7 \%)$ & $46(34.8 \%)$ \\
\hline \multicolumn{5}{|l|}{ Treatments } \\
\hline Intravenous immunoglobulin & $48(18.0 \%)$ & $22(20.6 \%)$ & $12(40.0 \%)$ & $82(20.3 \%)$ \\
\hline
\end{tabular}


medRxiv preprint doi: https://doi.org/10.1101/2021.10.28.21265616; this version posted November 8, 2021. The copyright holder for this preprint (which was not certified by peer review) is the author/funder, who has granted medRxiv a license to display the preprint in perpetuity. It is made available under a CC-BY-NC-ND 4.0 International license .

\begin{tabular}{|l|c|c|c|c|}
\hline Antiviral agent for influenza & $4(1.5 \%)$ & 0 & $4(13.3 \%)$ & $8(2.0 \%)$ \\
\hline Corticosteroids & $130(48.9 \%)$ & $30(28.0 \%)$ & $8(26.7 \%)$ & $168(41.7 \%)$ \\
\hline Lopinavir-ritonavir & 0 & 0 & $8(26.7 \%)$ & $8(2.0 \%)$ \\
\hline Remdesivir & $35(13.1 \%)$ & 0 & $6(20.0 \%)$ & $41(10.2 \%)$ \\
\hline Azithromycin & 0 & 0 & $13(43.3 \%)$ & $13(3.2 \%)$ \\
\hline Hydroxychloroquine & $1(0.4 \%)$ & 0 & $23(76.7 \%)$ & $24(5.9 \%)$ \\
\hline Highest level of care required & & & & \\
\hline $\begin{array}{l}\text { No supplemental oxygen or ICU } \\
\text { admission }\end{array}$ & $137(51.5 \%)$ & $38(35.5 \%)$ & $18(60.0 \%)$ & $193(47.9 \%)$ \\
\hline $\begin{array}{l}\text { Supplemental oxygen but no ICU } \\
\text { admission }{ }^{11}\end{array}$ & $47(17.7 \%)$ & $46(43.0 \%)$ & $2(6.7 \%)$ & $95(23.6 \%)$ \\
\hline ICU admission & $82(30.8 \%)$ & $23(21.5 \%)$ & $10(33.3 \%)$ & $115(28.5 \%)$ \\
\hline BIPAP/ MV & $45(16.9 \%)$ & $11(10.3 \%)$ & $6(20.0 \%)$ & $62(15.4 \%)$ \\
\hline ICU with CPAP/BIPAP & $18(6.8 \%)$ & $2(1.9 \%)$ & 0 & $20(5.0 \%)$ \\
\hline Extracorporeal life support & $19(7.1 \%)$ & $10(9.3 \%)$ & $4(13.3 \%)$ & $33(8.2 \%)$ \\
\hline $\begin{array}{l}\text { ICPAP/ } \\
\text { Complications }\end{array}$ & 0 & 0 & 0 & 0 \\
\hline MIS-C diagnosis & $59(22.2)$ & $19(17.7)$ & $3(10.0)$ & $81(20.1 \%)$ \\
\hline $\begin{array}{l}\text { Outcomes } \\
\text { definition and/or ICU admission }\end{array}$ & $91(34.2 \%)$ & $27(25.2 \%)$ & $10(33.3 \%)$ & $128(31.8 \%)$ \\
\hline $\begin{array}{l}\text { Mean length of hospitalization in days } \\
\text { Median length of hospitalization in } \\
\text { days (IQR) }\end{array}$ & $5.0(2.0-7.0)$ & $4.0(3.0-7.0)$ & $7.0(6.0-9.0)$ & $4.0(2.0-7.0)$ \\
\hline $\begin{array}{l}\text { Death } \\
\text { Severe disease according to WHO }\end{array}$ & $2(0.7 \%)$ & $3(2.8 \%)$ & $1(3.3 \%)$ & $6(1.5 \%)$ \\
\hline
\end{tabular}

BiPAP bilevel positive airway pressure; CPAP continuous positive airway pressure; CT computed tomography; CRP Creactive protein; CXR chest $\mathrm{x}$-ray; ICU intensive care unit; IQR interquartile range; MIS-C multisystem inflammatory syndrome in children; MV mechanical ventilation; SD standard deviation

${ }^{1}$ A total of 35 children were missing data on fever prior to or during admission ( 17 from Canada, 16 from Costa Rica and 2 from Iran) resulting in a total $\mathrm{N}$ of 368 .

${ }^{2}$ Children with one of the following are included: blood culture thought to be truly positive and/or positive endotracheal tube cultures treated with antibiotics for presumptive bacterial pneumonia and/or positive bacterial culture from another site treated with antibiotics.

${ }^{3}$ Children are listed more than once if they had more than one chest imaging result (e.g., chest x-ray and or chest CT).

${ }^{5}$ A total of 17 children were missing leukocyte values (14 from Canada and 3 from Costa Rica) resulting in a total $\mathrm{N}$ of 386.

${ }^{6}$ A total of 21 children were missing neutrophil values (18 from Canada and 3 from Costa Rica) resulting in a total $\mathrm{N}$ of 382. Cut-off values for neutrophilia are age dependent.

${ }^{7}$ A total of 18 children were missing platelet values (15 from Canada and 3 from Costa Rica) resulting in a total $\mathrm{N}$ of 385.

${ }^{8}$ A total of 60 children were missing a CRP value (41 from Canada and 19 from Costa Rica) resulting in a total $\mathrm{N}$ of 343.

${ }^{9}$ The variable assessing highest ferritin value used and a total of 220 children were missing a value (135 from Canada, 75 from Costa Rica and 10 from Iran) resulting in a total $\mathrm{N}$ of 183.

${ }^{10}$ A total of 271 children were missing albumin values (192 from Canada, 61 from Costa Rica and 18 from Iran) resulting in a total $\mathrm{N}$ of 132. 
medRxiv preprint doi: https://doi.org/10.1101/2021.10.28.21265616; this version posted November 8, 2021. The copyright holder for this preprint (which was not certified by peer review) is the author/funder, who has granted medRxiv a license to display the preprint in perpetuity. It is made available under a CC-BY-NC-ND 4.0 International license .

${ }^{11}$ Supplemental oxygen but no ICU admission includes those on oxygen, high flow nasal cannula, CPAP/BiPAP on regular or COVID-19 wards.

${ }^{12}$ A total of 4 children are missing date of discharge from hospital (2 from Canada and 2 from Iran). 
medRxiv preprint doi: https://doi.org/10.1101/2021.10.28.21265616; this version posted November 8, 2021. The copyright holder for this preprint (which was not certified by peer review) is the author/funder, who has granted medRxiv a license to display the preprint in perpetuity. It is made available under a CC-BY-NC-ND 4.0 International license .

Table 3. Characteristics of patients with severe PCR-positive SARS-CoV-2 infection $(n=403)$ according to severity of disease (WHO COVID-19 clinical progression scale of $\geq 6$ ).

\begin{tabular}{|c|c|c|c|c|}
\hline & $\begin{array}{c}\text { Mild/Moderate } \\
\text { Disease } \\
\text { N=301 }(\%)\end{array}$ & $\begin{array}{c}\text { Severe } \\
\text { Disease* } \\
\text { N=102 }(\%)\end{array}$ & $\begin{array}{c}\text { p- } \\
\text { value }^{* *}\end{array}$ & $\begin{array}{c}\text { Unadjusted OR of } \\
\text { severe disease }\end{array}$ \\
\hline \multicolumn{5}{|l|}{ Demographics } \\
\hline Median Age in years $(\mathrm{IQR})^{1}$ & $3.21(0.31-9.87)$ & $\begin{array}{c}6.69(1.31- \\
13.46)\end{array}$ & 0.002 & $1.05(1.01-1.09)$ \\
\hline Age $\leq 30$ days & $34(91.9 \%)$ & $3(8.1 \%)$ & 0.009 & $0.24(0.07-0.79)$ \\
\hline \multicolumn{5}{|l|}{ Age category ${ }^{1}$} \\
\hline$<1$ year & $94(83.2 \%)$ & $19(16.8 \%)$ & \multirow{4}{*}{0.025} & Ref. \\
\hline $1-4$ years & $79(74.5 \%)$ & $27(25.5 \%)$ & & $1.69(0.87-3.27)$ \\
\hline $5-11$ years & $66(74.1 \%)$ & $23(25.8 \%)$ & & $1.72(0.87-3.42)$ \\
\hline$\geq 12$ years & $60(64.5 \%)$ & $33(35.5 \%)$ & & $2.72(1.42-5.22)$ \\
\hline Male sex & $171(75.3 \%)$ & $56(24.7 \%)$ & 0.826 & $0.92(0.59-1.45)$ \\
\hline \multicolumn{5}{|l|}{ Admission period } \\
\hline Prior to July 1,2020 & $16(84.2 \%)$ & $3(15.8 \%)$ & \multirow{3}{*}{0.262} & Ref. \\
\hline Between July 1, 2020 to Dec 31, 2020 & $118(78.1 \%)$ & $33(21.8 \%)$ & & $1.49(0.41-5.43)$ \\
\hline Between Jan 1, 2021 to May 31, 2021 & $167(71.7 \%)$ & $66(28.3 \%)$ & & $2.11(0.59-7.47)$ \\
\hline Admitted in Canada & $195(73.3 \%)$ & $71(26.7 \%)$ & 0.442 & $1.24(0.77-2.02)$ \\
\hline \multicolumn{5}{|l|}{ Number of Comorbidities } \\
\hline None & $173(80.1 \%)$ & $43(19.9 \%)$ & \multirow{3}{*}{0.009} & Ref. \\
\hline 1 comorbidity & $81(72.3 \%)$ & $31(27.7 \%)$ & & $1.54(0.90-2.62)$ \\
\hline Multiple $(\geq 2)$ comorbidities & $47(62.7 \%)$ & $28(37.3 \%)$ & & $2.40(1.35-4.26)$ \\
\hline \multicolumn{5}{|l|}{ Individual Comorbidities $^{2}$} \\
\hline Obesity & $25(50.0 \%)$ & $25(50.0 \%)$ & $<0.001$ & $3.58(1.95-6.59)$ \\
\hline Pulmonary disorders & $35(64.8 \%)$ & $19(35.2 \%)$ & 0.104 & $1.74(0.94-3.20)$ \\
\hline Non-asthma pulmonary disorders ${ }^{3}$ & $12(54.5 \%)$ & $10(45.4 \%)$ & 0.047 & $2.62(1.09-6.26)$ \\
\hline Asthma & $23(71.9 \%)$ & $9(28.1 \%)$ & 0.865 & $1.17(0.52-2.62)$ \\
\hline Prematurity (<37 weeks gestational age) & $20(66.7 \%)$ & $10(33.3 \%)$ & 0.405 & $1.53(0.69-3.38)$ \\
\hline Immunosuppression & $26(83.9 \%)$ & $5(16.1 \%)$ & 0.284 & $0.54(0.20-1.46)$ \\
\hline Malignancy $^{4}$ & $15(93.7 \%)$ & $1(6.2 \%)$ & 0.083 & $0.19(0.02-1.45)$ \\
\hline Anemia or hemoglobinopathy ${ }^{5}$ & $7(53.8 \%)$ & $6(46.1 \%)$ & 0.152 & $2.62(0.86-8.00)$ \\
\hline Sickle cell anemia & $4(66.7 \%)$ & $2(33.3 \%)$ & 0.646 & $1.48(0.27-8.23)$ \\
\hline Neurological disorders $^{6}$ & $33(58.9 \%)$ & $23(41.1 \%)$ & 0.006 & $2.36(1.31-4.26)$ \\
\hline Cardiac disorders & $13(68.4 \%)$ & $6(31.6 \%)$ & 0.709 & $1.38(0.51-3.74)$ \\
\hline Metabolic disorders & $8(66.7 \%)$ & $4(33.3 \%)$ & 0.509 & $1.49(0.44-5.07)$ \\
\hline Diabetes mellitus & $3(60.0 \%)$ & $2(40.0 \%)$ & 0.604 & $1.99(0.33-12.06)$ \\
\hline Renal disorders & $9(64.3 \%)$ & $5(35.7 \%)$ & 0.357 & $1.67(0.55-5.11)$ \\
\hline Hypertension & $4(44.4 \%)$ & $5(55.5 \%)$ & 0.049 & $3.83(1.01-14.54)$ \\
\hline Chromosomal disorders $^{7}$ & $3(37.5 \%)$ & $5(62.5 \%)$ & 0.027 & $5.12(1.20-21.82)$ \\
\hline Other $^{8}$ & $17(68.0 \%)$ & $8(32.0 \%)$ & 0.578 & $1.42(0.59-3.40)$ \\
\hline \multicolumn{5}{|l|}{ Clinical Features } \\
\hline Fever prior to or during admission ${ }^{9}$ & $226(74.8 \%)$ & $76(25.2 \%)$ & 0.604 & $1.25(0.65-2.38)$ \\
\hline Cough & $147(70.7 \%)$ & $61(29.3 \%)$ & 0.071 & $1.56(0.99-2.46)$ \\
\hline Shortness of breath & $110(58.5 \%)$ & $78(41.5 \%)$ & $<0.001$ & $5.64(3.37-9.44)$ \\
\hline
\end{tabular}


medRxiv preprint doi: https://doi.org/10.1101/2021.10.28.21265616; this version posted November 8, 2021. The copyright holder for this preprint (which was not certified by peer review) is the author/funder, who has granted medRxiv a license to display the preprint in perpetuity. It is made available under a CC-BY-NC-ND 4.0 International license .

\begin{tabular}{|c|c|c|c|c|}
\hline Vomiting & $91(71.6 \%)$ & $36(28.3 \%)$ & 0.408 & $1.26(0.78-2.02)$ \\
\hline Rhinitis & $97(77.6 \%)$ & $28(22.4 \%)$ & 0.437 & $0.79(0.48-1.31)$ \\
\hline Diarrhea & $87(75.6 \%)$ & $28(24.3 \%)$ & 0.878 & $0.93(0.56-1.54)$ \\
\hline Abdominal pain & $80(74.1 \%)$ & $28(25.9 \%)$ & 0.966 & $1.04(0.63-1.73)$ \\
\hline Headache & $52(72.2 \%)$ & $20(27.8 \%)$ & 0.703 & $1.17(0.66-2.07)$ \\
\hline Rash & $50(72.5 \%)$ & $19(27.5 \%)$ & 0.753 & $1.15(0.64-2.06)$ \\
\hline Conjunctivitis & $46(67.6 \%)$ & $22(32.3 \%)$ & 0.189 & $1.52(0.86-2.69)$ \\
\hline Myalgia & $46(76.7 \%)$ & $14(23.3 \%)$ & 0.825 & $0.88(0.46-1.68)$ \\
\hline Pharyngitis & $50(83.3 \%)$ & $10(16.7 \%)$ & 0.131 & $0.54(0.26-1.12)$ \\
\hline Wheeze & $37(68.5 \%)$ & $17(31.5 \%)$ & 0.341 & $1.43(0.76-2.66)$ \\
\hline Chest pain & $27(69.2 \%)$ & $12(30.8 \%)$ & 0.528 & $1.35(0.66-2.78)$ \\
\hline Cracked lips & $26(68.4 \%)$ & $12(31.6 \%)$ & 0.461 & $1.41(0.68-2.91)$ \\
\hline Edema of hands and feet & $19(70.4 \%)$ & $8(29.6 \%)$ & 0.760 & $1.26(0.53-2.98)$ \\
\hline Anosmia & $10(83.3 \%)$ & $2(16.7 \%)$ & 0.738 & $0.58(0.12-2.70)$ \\
\hline Seizures & $6(54.5 \%)$ & $5(45.4 \%)$ & 0.155 & $2.53(0.76-8.49)$ \\
\hline \multicolumn{5}{|l|}{ Coinfections } \\
\hline Bacterial (positive cultures) $)^{10}$ & $14(58.3 \%)$ & $10(41.7 \%)$ & 0.097 & $2.23(0.96-5.19)$ \\
\hline Viral & $15(46.9 \%)$ & $17(53.1 \%)$ & $<0.001$ & $3.81(1.83-7.95)$ \\
\hline Bacterial and/or viral & $29(53.7 \%)$ & $25(46.3 \%)$ & $<0.001$ & $3.04(1.68-5.50)$ \\
\hline \multicolumn{5}{|l|}{ Investigations } \\
\hline No chest imaging done & $89(97.8 \%)$ & $2(2.2 \%)$ & \multirow{3}{*}{$<0.001$} & $0.12(0.03-0.53)$ \\
\hline $\begin{array}{l}\text { CXR and/or CT chest normal or had } \\
\text { findings unrelated to COVID-19 }\end{array}$ & $102(84.3 \%)$ & $19(15.7 \%)$ & & Ref. \\
\hline $\begin{array}{l}\text { CXR and/or CT chest abnormalities } \\
\text { compatible with COVID-19 }\end{array}$ & $110(57.6 \%)$ & $81(42.4 \%)$ & & $3.95(2.24-6.97)$ \\
\hline \multicolumn{5}{|l|}{ Laboratory investigations } \\
\hline Leukopenia $\left(<4 \times 10^{9} / \mathrm{L}\right)^{11}$ & $47(79.7 \%)$ & $12(20.3 \%)$ & 0.344 & $0.68(0.35-1.35)$ \\
\hline Leukocytosis $\left(>15 \times 10^{9} / \mathrm{L}\right)^{11}$ & $33(70.2 \%)$ & $14(29.8 \%)$ & 0.670 & $1.23(0.63-2.40)$ \\
\hline Neutropenia $\left(<1.5 \times 10^{9} / \mathrm{L}\right)^{12}$ & $69(82.1 \%)$ & $15(17.8 \%)$ & \multirow{3}{*}{$<0.001$} & $0.85(0.44-1.66)$ \\
\hline Normal neutrophil count $^{12}$ & $145(79.7 \%)$ & $37(20.3 \%)$ & & Ref. \\
\hline Neutrophilia $^{12}$ & $67(57.7 \%)$ & $49(42.2 \%)$ & & $2.87(1.71-4.80)$ \\
\hline Thrombocytopenia $\left(<100 \times 10^{9} / \mathrm{L}\right)^{13}$ & $29(69.0 \%)$ & $13(30.9 \%)$ & \multirow{3}{*}{0.275} & $1.44(0.70-2.94)$ \\
\hline Normal platelet count ${ }^{13}$ & $199(76.2 \%)$ & $62(23.7 \%)$ & & Ref. \\
\hline Thrombocytosis $\left(>450 \times 10^{9} / \mathrm{L}\right)^{13}$ & $56(68.3 \%)$ & $26(31.7 \%)$ & & $1.49(0.86-2.57)$ \\
\hline CRP not done ${ }^{14}$ & $51(85.0 \%)$ & $9(15.0 \%)$ & \multirow{3}{*}{0.003} & Ref. \\
\hline Normal CRP ${ }^{14}$ & $174(77.7 \%)$ & $50(22.3 \%)$ & & $1.63(0.75-3.53)$ \\
\hline $\mathrm{CRP}>50(\mathrm{mg} / \mathrm{L})^{14}$ & $76(63.9 \%)$ & $43(36.1 \%)$ & & $3.21(1.44-7.14)$ \\
\hline Ferritin $>500(\mathrm{mcg} / \mathrm{L})^{15}$ & $30(54.5 \%)$ & $25(45.4 \%)$ & 0.175 & $1.65(0.86-3.14)$ \\
\hline Albumin $<29(\mathrm{~g} / \mathrm{L})^{16}$ & $24(52.2 \%)$ & $22(47.8 \%)$ & 0.007 & $3.02(1.41-6.50)$ \\
\hline \multicolumn{5}{|l|}{ Complications } \\
\hline MIS-C diagnosis & $55(67.9 \%)$ & $26(32.1 \%)$ & 0.153 & $1.53(0.90-2.61)$ \\
\hline
\end{tabular}

OR Odds ratio; CT computed tomography; CRP C-reactive protein; CXR chest X-ray; IQR interquartile range; MIS-C multisystem inflammatory syndrome in children

* Percentages were calculated for the row, i.e., \% of a stratum with severe or mild/moderate disease.

** Comparisons performed using chi squared or Fisher's exact test as appropriate for categorical data and Wilcoxon rank sum test for continuous data as appropriate. 
${ }^{1}$ A total of 2 children with mild/moderate disease are missing date of birth.

${ }^{2}$ Children are listed more than once if they had more than one comorbidity.

${ }^{3}$ Additional information is available for 14/22 patients: obstructive sleep apnea $(n=5)$; bronchopulmonary dysplasia $(n=3)$; pulmonary hypertension $(\mathrm{n}=2)$; cystic fibrosis $(\mathrm{n}=1)$; chronic aspiration pneumonia $(\mathrm{n}=1)$; subglottic stenosis $(\mathrm{n}=1)$; PierreRobin anomaly $(\mathrm{n}=1)$

${ }^{4}$ Malignancy consists of the following: acute lymphoblastic leukemia $(n=11)$; neuroblastoma $(n=2)$; lymphoma $(n=1)$; rhabdomyosarcoma $(\mathrm{n}=1)$; and osteosarcoma $(\mathrm{n}=1)$

${ }^{5}$ Anemia and/or hemoglobinopathy consist of the following: sickle cell disease $(\mathrm{n}=6)$; Glucose-6-phosphate dehydrogenase deficiency $(n=2)$; anemia of chronic disease $(n=2)$; ovalocytosis $(n=1)$; pancytopenia of unknown etiology $(n=1)$; iron deficient anemia $(\mathrm{n}=1)$

${ }^{6}$ Additional information is available for 47/56 patients: syndromic condition with global developmental delay (GDD) $(\mathrm{n}=19)$; autism and/or GDD of unexplained etiology $(\mathrm{n}=10)$; cerebral palsy $(\mathrm{n}=7)$; muscular dystrophy $(\mathrm{n}=3)$; hydrocephalus $(n=2)$; congenital microcephaly $(n=2)$; brain tumor $(n=1)$; focal cortical dysplasia $(n=1)$; encephalopathy $(n=1)$; epilepsy $(\mathrm{n}=1)$

${ }^{7}$ Additional information is available for 7/8 patients: Trisomy $21(\mathrm{n}=3)$; unbalanced translocation $(\mathrm{n}=2)$; Prader-Willi syndrome $(\mathrm{n}=1)$; Miller-Dieker syndrome $(\mathrm{n}=1)$

${ }^{8}$ Other consist of the following: gastrostomy $(n=12)$; liver transplantation $(n=2)$; celiac disease $(n=1)$; Crohn's disease $(n=1)$ failure to thrive $(n=1)$; inflammatory bowel disease $(n=1)$; inflammatory bowel disease and Hirschsprung disease $(n=1)$; unclear liver disease $(n=1)$; esophageal atresia $(n=1)$; scoliosis $(n=2)$; liver cirrhosis \& cholestasis $(n=1)$; Glanzmann thrombasthenia $(\mathrm{n}=1)$

${ }^{9} \mathrm{~A}$ total of 35 children were missing data on fever prior to or during admission ( 23 with mild/moderate disease and 12 with severe disease) resulting in a total $\mathrm{N}$ of 368 .

${ }^{10}$ Children with one of the following are included: blood culture thought to be truly positive and/or positive endotracheal tube cultures treated with antibiotics for presumptive bacterial pneumonia and/or positive bacterial culture from another site treated with antibiotics.

${ }^{11}$ A total of 17 children were missing leukocyte values (16 with mild/moderate disease and 1 with severe disease) resulting in a total $\mathrm{N}$ of 386.

${ }^{12}$ A total of 21 children were missing a neutrophil value ( 20 with mild/moderate disease and 1 with severe disease) resulting in a total $\mathrm{N}$ of 382. Cut-off values for neutrophilia are age dependent.

${ }^{13}$ A total of 18 children were missing a platelet value (17 with mild/moderate disease and 1 with severe disease) resulting in a total $\mathrm{N}$ of 385 .

${ }^{14}$ A total of 60 children were missing a CRP value (51 with mild/moderate disease and 9 with severe disease) resulting in a total $\mathrm{N}$ of 343 .

${ }^{15}$ The highest ferritin value measured variable used and a total of 220 children were missing a value (186 with mild/moderate disease and 34 with severe disease) resulting in a total $\mathrm{N}$ of 183.

${ }^{16}$ A total of 271 children were missing albumin values (211 with mild/moderate disease and 60 with severe disease) resulting in a total $\mathrm{N}$ of 132 . 